\title{
Repositioning Senior Secondary Education in Nigeria for Producing Entrepreneurial-Oriented Students
}

\author{
Ohia, Adanma Ngozi ${ }^{1, *}$ \& Obasi, Kenneth Kelechi ${ }^{1}$ \\ ${ }^{1}$ Faculty of Education, University of Port Harcourt, Port Harcourt, Rivers State, Nigeria \\ *Corresponding author: Faculty of Education, University of Port Harcourt, Port Harcourt, Rivers State, Nigeria. Tel: \\ 234-803-306-4054. E-mail: ohiaadanma@yahoo.com
}

Received: April 26, 2014

Accepted: May 23, $2014 \quad$ Online Published: June 12, 2014

doi:10.5430/wje.v4n3p75

URL: http://dx.doi.org/10.5430/wje.v4n3p75

\begin{abstract}
This paper brings to the fore a realization of the fact that the performance of the products (outputs) of the education system is an index of the inputs into the system. For the students to have enterprising and innovative mindsets, it is important to expose them early to practical entrepreneurial and vocational skills while in school. This study therefore sought to identify what skills are imparted to the students practically and the teaching/learning exercises used. The research design was descriptive survey. Government Secondary Schools (236) in Rivers State, Nigeria constituted the population. Proportionate stratified random sampling technique was used to get a sample size of 70 (30\%) senior secondary schools. The total respondents were 140 made up of 70 principals and 70 vice-principals. Three research questions and one hypothesis guided the study. Data were collected using structured questionnaire. The instrument reliability was established using test re-test method (r-coefficient was 0.82 ), Mean $(X)$ and standard deviation (SD) were used to answer the research questions and the hypothesis analysed using t-test at 0.05 level of significance. Practically the students were taught some vocational skills like agriculture, technical drawing, food and nutrition. The entrepreneurial skills imparted to them are communication skills, personality skills, and digital literacy skills. It was recommended among other things that the students should be exposed to more practical skills. Students centered teaching/learning exercise need to be used to encourage active participation of the student.
\end{abstract}

Keywords: senior secondary education; entrepreneurial skills; vocational skills; teaching/learning exercises

\section{Introduction}

In Nigeria, senior secondary education is the education a child receives in his/her last three years at the secondary education level after nine years of basic education and before four or five years of tertiary education. So important is this segment of the education sector because of the dual consumer and producer roles it plays. By absorbing the products of the basic education system, it plays the consumer role, and by making available students for the tertiary level of education, it plays the producer role (Ohia, 2010). One of the specific objectives of secondary education in Nigeria is to "provide technical knowledge and vocational skills necessary for agriculture, industrial, commercial and economic development.” (F.R.N, 2004:19). This objective, as observed by Madumere and Salisu (2007), is closely related to the goals of Technical and Vocational Education (TVE).

The Federal Republic of Nigeria, in the National Policy on Education (FRN, 2004) categorized senior secondary school subjects into: group A with six (6) core subjects the students are to offer, including a vocational subject. Eighteen (18) vocational subjects were listed in group B and sixteen (16) non-vocational subjects in group C as electives. The students are expected to select a minimum of one or a maximum of two subjects from groups B and C. They are also at liberty to drop one in their last year in secondary school. In the light of the above, there seems to be more emphasis on the students' acquisition of theoretical rather than practical skills at this level. But Rich (2002) asserted that skills make rich, not theory.

Now, with the reawakening consciousness of globalization, efforts should be geared towards making the students from the senior education level enterprising in preparation for global competitiveness. To this extent, the students are expected to be presented a formal education that will make them have entrepreneurial orientation, be creative and 
innovative.

A wide range of competencies are needed to make these students have entrepreneurial mind-set and also enhance their acquisition and appreciation of practical vocational skills: Entrepreneurship, as posited by Ibe and Ugboja (2008), is induced by the motives, creativity and skills of an individual. Entrepreneurship is an act of being an entrepreneur, that is, one who undertakes innovations (Wikipedia, n.d.). Obasi (2009) opined that entrepreneurship is a practice that has a knowledge base which is a means to an end; adding that knowledge is largely defined by the end, which invariably, is the practice. Entrepreneurship therefore should not be separated from education, being a life-long process. No wonder Osuala (2009) advocated the inclusion of entrepreneurship education in the school curricula at all levels. This type of education exposes the students to specialised training to help them acquire vocational skills (Olorumola and Agbede, 2012). This is essential to help the students transform ideas into economic opportunities which is the crux of entrepreneurship. Entrepreneurship education is an effort at identifying the resources available in a country and designing the educational curricula such that it imparts on the people (Ebong and Leigha, 2009).

There are many theories of entrepreneurship but Schultz theory of entrepreneurship: the human capital approach is adopted to support this study. Entrepreneurship ability is seen as a form of human capital which can be acquired through education, training, experience and other practices. But the focus of this study is on the education aspect (Bula, 2012). A general theory of entrepreneurship: the individual opportunity nexus (shane and Eckhardt, 2003) in the researchers' opinion lends credence to that of Schultz (1961) as entrepreneurship is seen as a combination of the presence of lucrative opportunities and enterprising individuals. The appropriateness of this theory in this study is hinged on the importance of planning the teaching/learning activities in Nigeria's secondary schools to make the students at the early stage to have entrepreneurial interests that will enable them to easily identify the existence of any available lucrative opportunity.

To be entrepreneurial-oriented, the students need to be exposed to practical entrepreneurial skills while in school. The skills will make them successful and useful entrepreneurs in whatever profession or field of endeavour they may undertake after secondary school. Every subject has a practical aspect as Uche and Adesope (2009) advocated that each subject be taught to bring out the hidden potentials it contains in the areas of self employment, job and wealth creation. They also listed some entrepreneurial skills such as communication skills, risk taking skills and business management skills. There are many entrepreneurial skills but, this study chose the skills it considered to have direct bearing on the students at this stage for instance: communication skills, sales skills, leadership skills, digital literacy skills, innovative skills and personality skills. It is hoped that to sharpen their desires to be self-reliant, they also need to acquire in addition some practical vocational skills. Vocational skills are practical skills that one acquires on a specific area of interest such as artwork, gardening, carpentry, tailoring, metal work, (the choices are many).

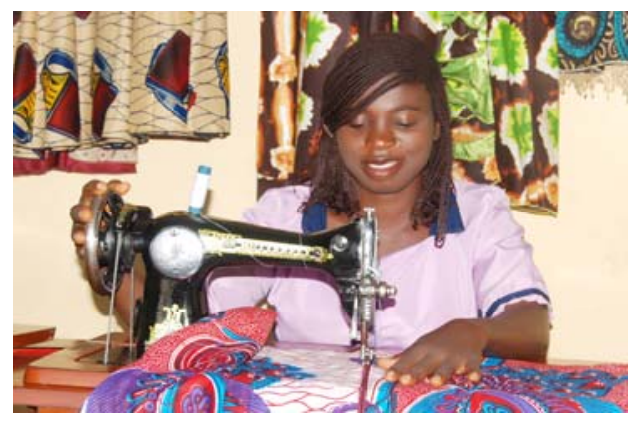

Figure 1. Tailoring

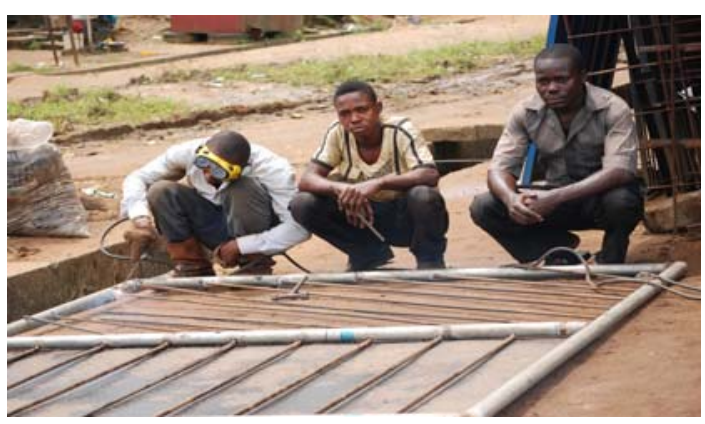

Figure 2. Metal Work

Suttle (n.d.) explained that vocational skills are the skills that enable someone not just to master a subject but also the procedure that can be applied in a career. Explaining further that, vocational skills can be developed by some people in high school. Although, it is believed that vocational skills are acquired in specialized schools, but senior secondary schools generally can be repositioned to also teach the students some practical skills. These skills should be made more practical than theoretical; to encourage the use of their hands and brains to work to ultimately earn a living and make positive contributions to the society.

Making the students active participants in the teaching/learning process is important and entails a review of the teaching/learning exercises used in teaching them. Teaching/learning exercises are seen in this study as those activities of the teacher/instructor geared towards ensuring that learning takes place faster and permanently. The 
study identified such activities like role playing, simulations, student focused-learning feedbacks and less "listen and take" note method. The student focused or student-centered learning activity lays emphasis on the students; what they learn and how they actualize their own learning (Harden and Crosby, 2000). Simulation has to do with doing repeatedly an activity and presenting same with reference to some specific purposes. Pittaway and Cope (2007) opined that entrepreneurial learning could be simulated. The students could be made to exhibit their hidden talents. These activities could enhance students' participation in the teaching/learning exercise as against the teacher-centered practices that make the students to just listen, take note and be passive receivers of instructions.

The importance of educational planners in redesigning of educational programmes of secondary schools in Nigeria cannot be over-emphasized. The teaching of some practical skills will involve an aspect of school plant planning because "it is the education programme that determines what plants and facilities that are needed for instructional purposes" (Madumere, 2007:62). To reposition secondary schools to provide the students with valuable life-long skills will require, in addition to other things, provision of appropriate school plants and facilities to enhance the teaching/learning exercises.

\subsection{Statement of the Problem}

There seems to be a general expectation that the senior secondary students graduate from this level of education to proceed immediately to the tertiary level. But in a situation where some of the students do not gain admission immediately into higher institutions, what practical entrepreneurial and vocational skills can they confidently put into practice having acquired such skills while in school? The problem therefore is to reposition the teaching/learning activities in senior secondary schools to equip the students with "life-sustaining" skills.

\subsection{Purpose of the Study}

How to reposition senior secondary education to make the students have entrepreneurial orientation is the general purpose. Specifically the study sought to

a. identify the practical vocational skills senior secondary students are taught;

b. $\quad$ find out what entrepreneurial skills are imparted to the students;

c. determine the teaching/learning exercises used in teaching the students to re-orientate their mindset.

\subsection{Research Questions}

1. What practical vocational skills are the senior secondary students taught?

2. What entrepreneurial skills do the teachers impart to the students?

3. What teaching/learning exercises are used in teaching the students?

\subsection{Research Hypothesis}

Ho1: There is no significant difference in the opinions of principals and vice principals on the practical teaching of vocational skills to the students.

\section{Methodology}

The design of the study was descriptive survey. This design collected data to ascertain the status quo in senior secondary schools. Government senior secondary schools in Rivers State constituted the population with a numerical strength of 236. The sample size was 70 (30\%) got by proportionate stratified random sampling technique.

The instrument for collecting data was a structured questionnaire titled "Repositioning Senior Secondary Education for Entrepreneurial-Oriented Student Questionnaire” (RSSEEOSQ). The questionnaire had four sections - A, B, C, and D. The response mode was the modified Likert 4-point scale of Strongly Agree (4), Agree (3), Disagree (2) and Strongly Disagree (1).

The content validity of the instrument was done by educational planning experts. To establish the reliability, test-retest method was done. The responses were computed using Pearson Product Moment Correlation Coefficient (r). The reliability index was 0.82 . The researchers administered the questionnaire to 70 principals and 70 vice principals in ten local government areas of Rivers State. Mean scores and standard deviation were used to analyze the research questions. The null hypothesis was tested using t-test at 0.05 level of significance and 138 degree of freedom. 


\section{Result and Discussion}

Practical Vocational Skills taught the students

The practical teaching of eight vocational skills was surveyed and the result is presented in table 1.

Table 1. Mean \& Standard Deviation of the Responses on the Vocational Skills Taught the Students

\begin{tabular}{llllllll}
\hline & & \multicolumn{4}{c}{ Principals } & \multicolumn{3}{c}{ Vice-Principals } \\
\cline { 2 - 8 } S/No. & Items & $\bar{X}$ & SD & Decision & $\bar{X}$ & SD & Decision \\
& & & & & & \\
\hline 1 & Agriculture & 3.55 & 0.59 & Agree & 3.38 & 0.99 & Agree \\
2 & Building construction & 2.00 & 1.08 & Disagree & 2.10 & 1.93 & Disagree \\
3 & Fashion desiring & 2.34 & 1.11 & Disagree & 2.35 & 1.12 & Disagree \\
4 & Fine Arts & 2.05 & 1.03 & Disagree & 2.18 & 1.05 & Disagree \\
5 & Technical Drawing & 2.75 & 1.65 & Agree & 2.78 & 1.66 & Agree \\
6 & Metal work & 2.00 & 1.01 & Disagree & 2.00 & 1.11 & Disagree \\
7 & Music & 2.10 & 1.03 & Disagree & 2.00 & 1.08 & Disagree \\
8 & Food \& Nutrition & 2.70 & 1.60 & Agree & 2.72 & 1.62 & Agree \\
\hline Criterion mean $=2.50$ on a 4-point scale & & & & & \\
\hline
\end{tabular}

Students are availed the opportunity of learning practically Agriculture (3.55), Technical drawing (2.75), and Food \& Nutrition (2.70). But Fashion designing, Fine Arts, Metal work and Music are rarely taught practically as the weighted mean opinion scores for these skills range between 2.00 and 2.34 .

Practical entrepreneurial skills imparted to the students are as presented in table 2

Table 2. Mean and Standard Deviation of the Responses on the Entrepreneurial Skills Imparted to the Students

\begin{tabular}{llllllll}
\hline & \multicolumn{3}{c}{ Principals } & & \multicolumn{3}{c}{ Vice-Principals } \\
\cline { 2 - 8 } S/No. & Skills & $\bar{X}$ & SD & Decision & $\bar{X}$ & SD & Decision \\
& & & & & & & \\
\hline 9 & Communication & 2.79 & 1.15 & Agree & 2.70 & 1.2 & Agree \\
10 & Sales & 2.00 & 1.013 & Disagree & 2.10 & 1.06 & Disagree \\
11 & Leadership & 1.78 & 0.95 & Disagree & 1.75 & 0.93 & Disagree \\
12 & Digital literacy & 2.71 & 1.11 & Agree & 2.65 & 1.10 & Agree \\
13 & Innovative & 2.24 & 1.12 & Disagree & 2.22 & 1.11 & Disagree \\
14 & Personality & 2.92 & 1.17 & Agree & 2.94 & 1.19 & Agree \\
\hline
\end{tabular}

Table 2 shows that the students were imparted communication skills, digital literacy skills and personality skills (Mean scores $=2.79,2.71$ and 2.92 respectively). Sales skills, leadership skills and innovative skills had mean scores less than the criterion mean of 2.50. The students do not receive practical teaching on these skills.

The teaching/learning exercises used in teaching the students are presented in table 3.

Table 3. Mean and Standard Deviation of the Responses about the Teaching/Learning Exercises Used

\begin{tabular}{llllllll}
\hline & \multicolumn{4}{c}{ Principals } & \multicolumn{5}{c}{ Vice-Principals } \\
\cline { 2 - 8 } S/No. & \multicolumn{1}{c}{ Items } & $\bar{X}$ & SD & Decision & $\bar{X}$ & SD & Decision \\
& & 2.69 & 1.02 & Agree & 2.67 & 1.04 & Agree \\
\hline 15 & Role playing & 2.31 & 1.01 & Disagree & 2.30 & 1.00 & Disagree \\
16 & Simulations & 1.93 & 0.89 & Disagree & 1.95 & 0.91 & Disagree \\
17 & Student focused-learning feedbacks & & & & & \\
18 & Less “listen and take” note method & 1.88 & 0.83 & Disagree & 1.86 & 0.80 & Disagree \\
\hline
\end{tabular}


It is evident from Table 3 that role playing, as a teaching/learning exercise is used in teaching the students, the mean score is 2.69.The traditional method of "listen and take" note is still being practiced. Simulations and student focused-learning feedbacks are not explored too.

Hypothesis 1: There is no significant difference in the opinions of principals and vice principals on the practical teaching of vocational skills to the students.

Table 4. T-Test Analysis of the Mean Scores of the Opinions of Principals and Vice Principals on the Practical Teaching of Vocational Skills to the Students

\begin{tabular}{lllllcll}
\hline & $\mathrm{N}$ & Mean & SD & df & t-calculated & t-critical & Remarks \\
\hline Principals & 70 & 2.60 & 2.46 & 138 & 0.74 & 1.96 & Not \\
Vice-principals & 70 & 2.60 & 2.80 & & & & significant \\
\multicolumn{1}{c}{$\mathrm{P}<0.05$} & & & & & & & \\
\hline
\end{tabular}

Table 4 indicates that the t-calculated value of 0.74 is less than the t-critical of 1.96 at 138 degree of freedom and 0.05 level of significant. The null hypothesis is therefore not rejected.

\section{Conclusion}

When students are taught practical skills not in theory only, it helps to bring out their creative capabilities. It is very expedient now for secondary school activities to be repositioned in consonance with contemporary realities building up the mindset of the student right from the secondary school stage to be enterprising.

Acquiring practical entrepreneurial and vocational skills in secondary school will not impede their pursuit of the career of their choice in tertiary institutions; instead it will enable them to make use of both their hands and brains to work to ultimately earn a living. Presently these students study less practical skills. Their entrepreneurial ability could be increased by exposing them to more practical skills.

De-emphasizing the theoretical approach to the teaching/learning activities in secondary schools and creating an opportunity to expose the students to a good mix of both conventional subjects and practical vocational skills will make them come out from school better equipped to be self-reliant.

\section{Recommendations}

Students should be taught practical vocational skills like fashion designing, fine arts, metal work and music. It will be beneficial to the students if they receive practical teaching in sales, leadership and innovative entrepreneurial skills. Finally, more practical teaching/learning exercises like role play, simulations and student-focused learning feedbacks should be implored in order to make the students active participants in the teaching/learning process.

\section{References}

Bula, H.O. (2012). Evolution and Theories of Entrepreneurship: a critical review on the Kenyan Perspective. International Journal of Business and Commerce, 1(11), 81-96. Retrieved from http://www.ijbenet.com May 16, 2014

Ebong, J. M., \& Leigha M. B. (2009). Re-aligning policy with socio-economic realities for effective development of entrepreneurship in secondary education in Nigeria. African Journal of Educational Research and Development, 3(2), 351-358.

Federal Republic of Nigeria. (2004). National Policy on Education. Abuja: Nigerian Educational Research and Development.

Harden, R.M., \& Crosby, J.R. (2000). The good teacher is more than a lecturer - the Twelve Roles of the Teacher. AMEE Medical Education Guide No 20. Scotland: Lynn Bell. Retrieved May 18, 2014 from htt://www.wikieducator.org/images/e/e3/Twelve-Roles_of_a_Lecturer.pdf

Ibe, C. C., \& Ugboaja, P. C. (2000). Entrepreneurial and strategic thinking. African Journal of Entrepreneurship, $1(1), 17-30$. 
Madumere, S.C. (2007). School plant planting, facilities management and educational law. Lagos: Okoye Honeybees.

Madumere, S.C., \& Salisu, R.A. (2007). Policy issues in the Skill-Oriented Education Sub-Sector and National Development. In J.B. Babalola, G.O. Akpa and A.O. Ayeni (Eds.), Managing Technical and Vocational Education in the era of globalization, p405 - 411. NAEAP 2007 publication.

Obasi, K. K. (2009). Entrepreneurial scholarship in the light of the human capital thesis: the Nigerian secondary education challenge. African Journal of Educational Research and Development, 3(2), 385-394.

Ohia, A. N. (2010). Quality of learning resources available accessible to students in public secondary schools in Abia State. Unpublished Ph.D dissertation, University of Port Harcourt.

Olorumolu, J. O., \& Agbede, A. E. (2012). Quality entrepreneurship education: a panacea for job creation in Nigeria. Journal of resourcefulness and distinction, 1(1), 175-190. Retrieved March 24, 2013, from http://www.wesoeduonline.com/journals/resourcefulness

Osemwegie, A. (2013). The impact of schools on unemployment. Peoples’ Digest. p. 28.

Osuala, K. N. (2009). Entrepreneurial education in tertiary institution as a tool for poverty alleviation among Nigerian women. African Journal of Educational Research and Development, 3(2), 40-48.

Pittaway, L., \& Cope, J. (2007). Simulating entrepreneurial learning: Integrating experiential and collaborative approaches to learning. Management Learning, 38(2), 211-233. http://dx.doi.org/10.1177/1350507607075776

Rich, D. (2002). 21st century skills and capabilities. Retrieved April 5, 2013 from http://www.larkslearning.com/blog/category/

Shane, S., \& Eckhardt, J. (2003). The individual -opportunity Nexus. In Z. Acs and D. Audretsch (Eds.), Handbook of Entrepreneurship research: an inter disciplinary survey and introduction. Boston: Kluwer. Academic.

Suttle, $\mathrm{R}$ (n.d.) Examples of Vocational Skills. Retrieved May 10, 2014 from http://www.ehow.com/list-660040-examples-vocational-skills.html

Uche, C. M., \& Adesope, O. M. (2009). Capacity building for entrepreneurship education: state of the art in University of Port Harcourt, Nigeria. African Journal of Educational Research and Development, 3(2), 86-98.

Wikipedia, the free Encyclopedia (n.d.). Retrieved May 2, 2013, from http://en.wikipedia.org/wiki/Entrepreneurship 